\title{
SPATIAL CHARACTERISTICS AND GEOGRAPHICAL DETERMINANTS OF INCOME POVERTY IN TURKEY
}

DOI: http://dx.doi.org/10.18509/GBP.2017.34

UDC: 911.3:33(560)

\author{
Öznur Akgiş \\ Erdal Karakaş \\ Bilecik Şeyh Edebali University, Department of Geography, Turkey
}

\begin{abstract}
As a developing country poverty rates have fallen statistically in all provinces of Turkey. Nevertheless poverty is still one of the most important socio-economic problems. Even if the proportion of people living under hunger limit decreases, the proportion of "population with risk of poverty" is still high that is a negative table. When the low per capita income combined with unequal spatial distribution, there is a distinct spatial segregation in the country.

In this context the purpose of the study is to explain the distribution of income poverty in Turkey and determine geographical factors that are effective in this distribution. Poverty and inequality statistics were used in this study according to the NUTS2 regions prepared by Turkish Statistical Institute (TURKSTAT) for 2015. Considering the geographical characteristics of the regions, poverty inferences were made and related maps were developed.

TR61 and TRA 2 regions are the areas where poverty is mostly experienced. The area with the lowest rate of poverty is seen as TRB2. According to the results, it is seen that high inequality rates, physical capital, terrorism and migration are the most important factors affecting the distribution of poverty rates. As a result the reason of spatial distribution of poverty can be differentiated in different regions even in a single country. Turkey is the best model of this thesis.
\end{abstract}

Keywords: Economic Geography, Poverty, Income, Inequality, Turkey

\section{INTRODUCTION}

In many countries there are apparent regional differences in living standards. These inequalities cause the formation of "poverty pockets" in both poor and rich countries [6]. Spatial disparities in the distribution of poverty lead to the question of why poor areas have emerged and at what stage geography is decisive in this distribution [9].

Studies about poverty always focus on demographical variables of the issue and spatial characteristics are not taken into account sufficiently. However economic and social status of individuals shape by advantages and disadvantages of space. According to this it is possible to say that poverty is directly associated with geography [2]. Therefore identifiying spatial patterns of poverty help describing problem and provide new insights into the causes of it [8]. In addition according to Ravallion and Huppi [10] comparisions of the magnitude and severity of poverty can provide direct evidence of an economy's progress and living standard of citizens. Baker and Grosh [4] entitled this as "geographical targeting" and they argue that geographical targeting is a relevant tool to maximizing the coverage of poor while minimizing leakage to the non-poor. 
Bazin and De Tapia [5] state that nowadays Turkey is accepted as a political precept and the country has a place in globally rising forces with its demographic and economic characteristics. Although the poverty rates of Turkey after modernization and industrialization are decreasing, poverty has always been a problem Due to the economic conjuncture, the fight against poverty, which became more severe in times of crisis, is on the agenda of the Turkish economy with increasing importance. As a result, there has been an increasing in poverty-related work in recent years [7].

As a developing country poverty rates have fallen statistically in all provinces in Turkey. Nevertheless poverty is still one of the most important problems. Even if the proportion of people living under hunger limit in the country decreases, the proportion of "population with risk of poverty" (Household net income equal to the equivalence scale is below $60 \%$ of the median) is still high, which is a negative table. When the low per capita income combined with the spatially unequal distribution, there is a distinct spatial segregation in the country.

The aims of this study are to explain the current situation of income poverty in Turkey, to express the distribution of income poverty according to NUTS2 regions and to determine the geographical determinants that are effective in this distribution.

\section{MATERIAL AND METHODS}

This is a descriptive study in which quantitative research methods are used. First, poverty rates calculated according to equivalent household income between 2006 and 2015 have been evaluated to express the general situation of poverty and recent changes in Turkey. In addition, the poverty rates calculated by taking into account the education level and the household income are briefly stated.

Poverty and inequality statistics were used in the study according to the NUTS 2 regions prepared by the Turkish Statistical Institute (TURKSTAT) for 2015 to able to interpret the spatial characteristics of income poverty. Considering the geographical characteristics of the regions, poverty inferences were made and related maps were developed.

\section{RESULTS}

When the poverty rates between 2006 and 2014 are examined, it is seen that there is a decrease of approximately $3 \%$. Likewise, the population living below $60 \%$ of the median income, which represents the population with the risk of poverty, has also declined. Concordantly, the poverty gap tends to fall between the mentioned years (Figure 1) It is noteworthy that the 2008 economic crisis did not cause a significant change in the country's poverty rates.

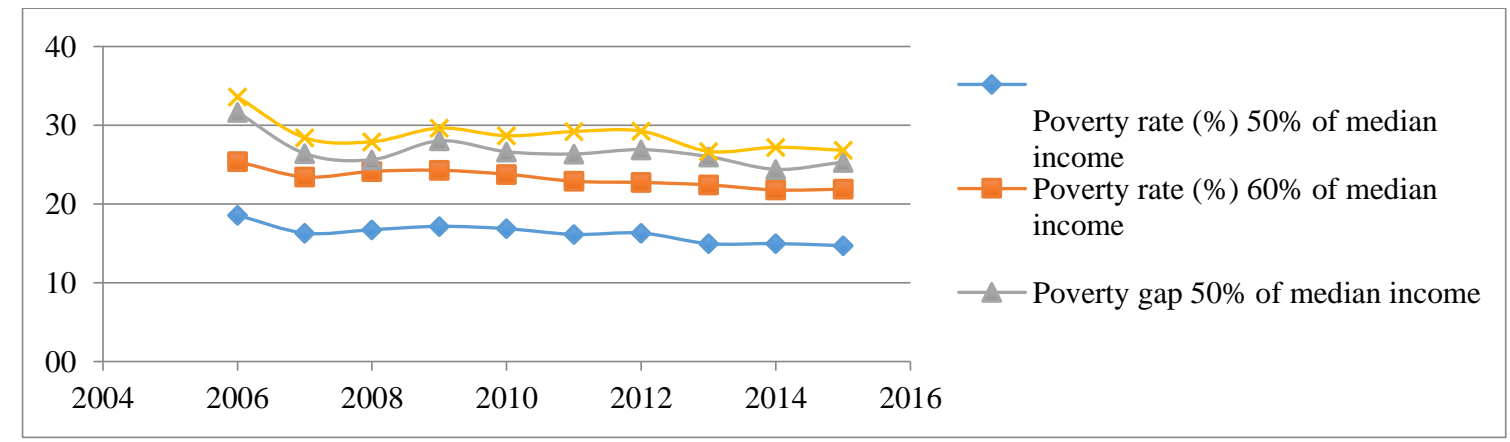

Figure 1. Poverty rate and poverty gap by equivalised household disposable income, 2006-2015 
Figure 2 was prepared in order to determine how the poverty differs according to household type in Turkey. Single-person households have the lowest poverty rate. Parents who have children have the highest rate of poverty. Accordingly, if the total number of children in household increase then poverty rates increase. For this reason it is seen that there is a positive correlation between poverty and household size.

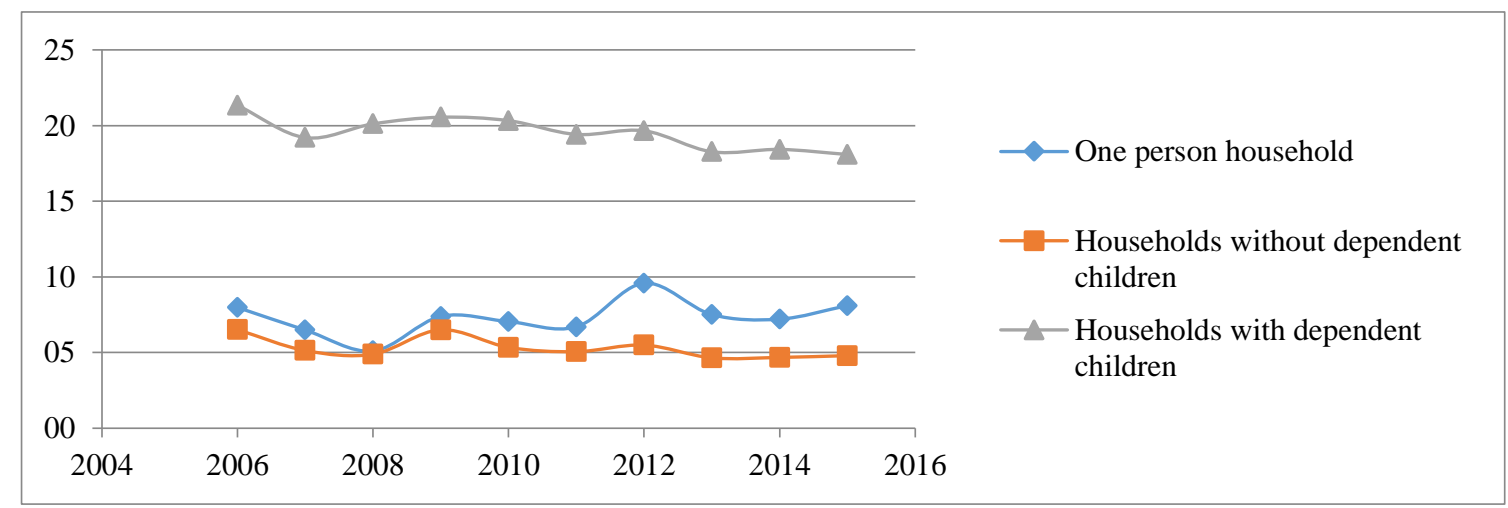

Figure 2. Poverty rate and household type by equivalised household disposable income, 2006-2015

Figure 3 shows the poverty rates of the population by educational status. When the relationship between educational status and poverty rates is examined, it is noteworthy that they differ according to education level and years. By 2015, the illiterate population has the highest poverty rates. When Figure 3 is examined, it is seen that poverty rate decreases due to the increase of education level.

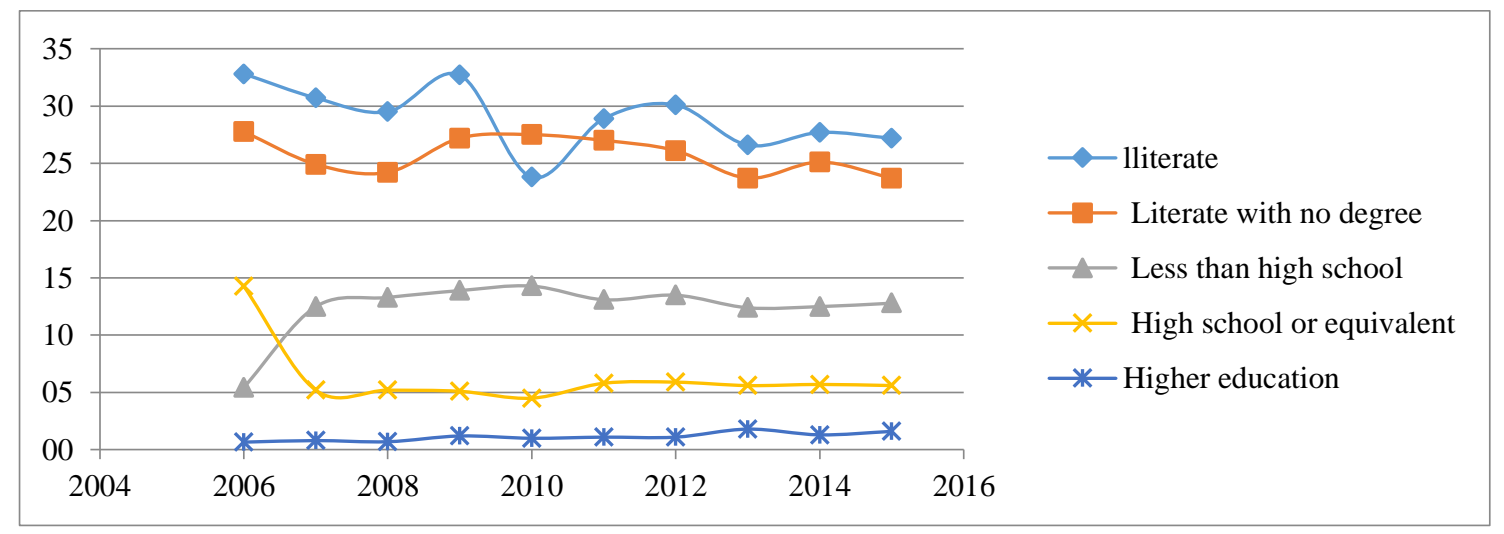

Figure 3. Poverty rate by education level and equivalised household disposable income, 2006-2015

According to the findings, TR61 and TRA2 regions are the areas where poverty rates are the highest. The average altitude of the TRA2 region is quite high and climate characteristics of the region is quite difficult compared to other regions (Figure 4) The pitch in the field is excessively high because of this land use capability is very low. At the same time this region has one of the highest rural population and lowest industrialization ratios of the country. Accordingly, the basic economic activities of people are livestock and agriculture. In livestock sector cattle-raising is in the front plan and in agriculture they produce grain for use as an animal feed. Since the modern production methods both agriculture and animal husbandry have not become widespread. Therefore acquired income from these activities is quite low. The disadvantages of both 
physical and social environment have led the region to become the poorest area in the country.

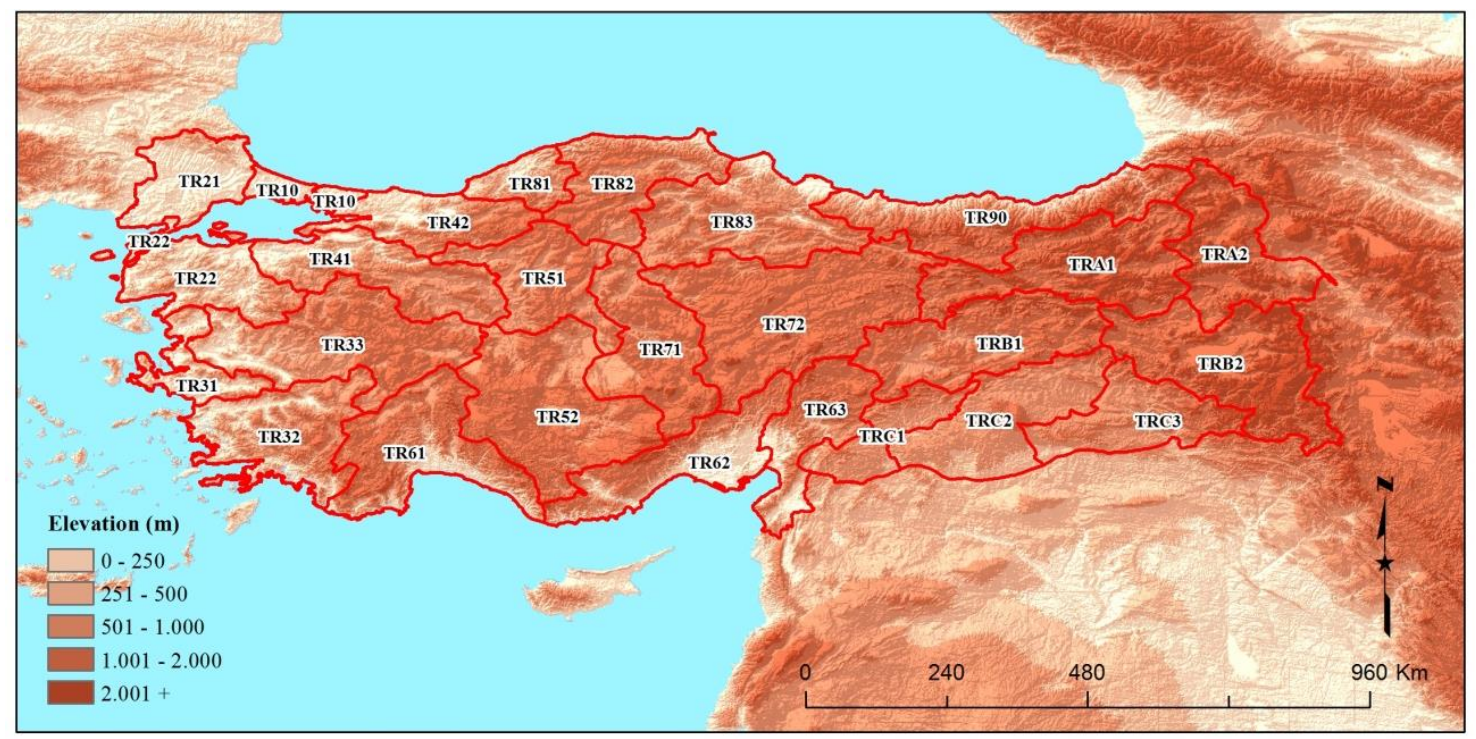

Figure 4. Elevation map of Turkey

The second region with the highest poverty rate is TR62 region. The region is one of the most important area in the country in terms of agriculture and tourism. Especially Antalya province in this region is one of the most important tourism destination of Turkey. In agricultural activities citrus cultivation is also highly developed and this area meets a large part of the country's exports alone. However, it is striking that poverty rates in the region are so high. The study conducted by Akgiş and Karakaş [3] determined that immigrant that migrating from Southern Anatolia to the region aggregately and residence of hundreds of Syrian refugees are the most important reasons of high poverty rates. The number of Syrian refugees living in Turkey in 2016 is 2 million 750 thousand. Only 300.000 of them live in 26 camps in the country. Most of them live in urban areas. The places where they live intensely are the southern provinces and big cities of the country. Even the population of refugees has exceeded the local population in some places. For example, in the province of Kilis, (it is located within the TRC1). The proportion of the local population is over 90,000 and the number of refugees is over 130,000 [1].

Until the year 2010, the region that has the highest poverty rates was Southeastern Anatolia after TRA2 region. However, with the increasing of terrorist incidents in the region, in the following years most of the population has migrated to TR62 region, especially Antalya that has significant economic potential. Because, there are too many seasonal employment opportunities in both tourism and agriculture. This is an important attracting force for migration. Both internal and external migration, and the low profile of the migrant is the main cause of the poverty in the region. 

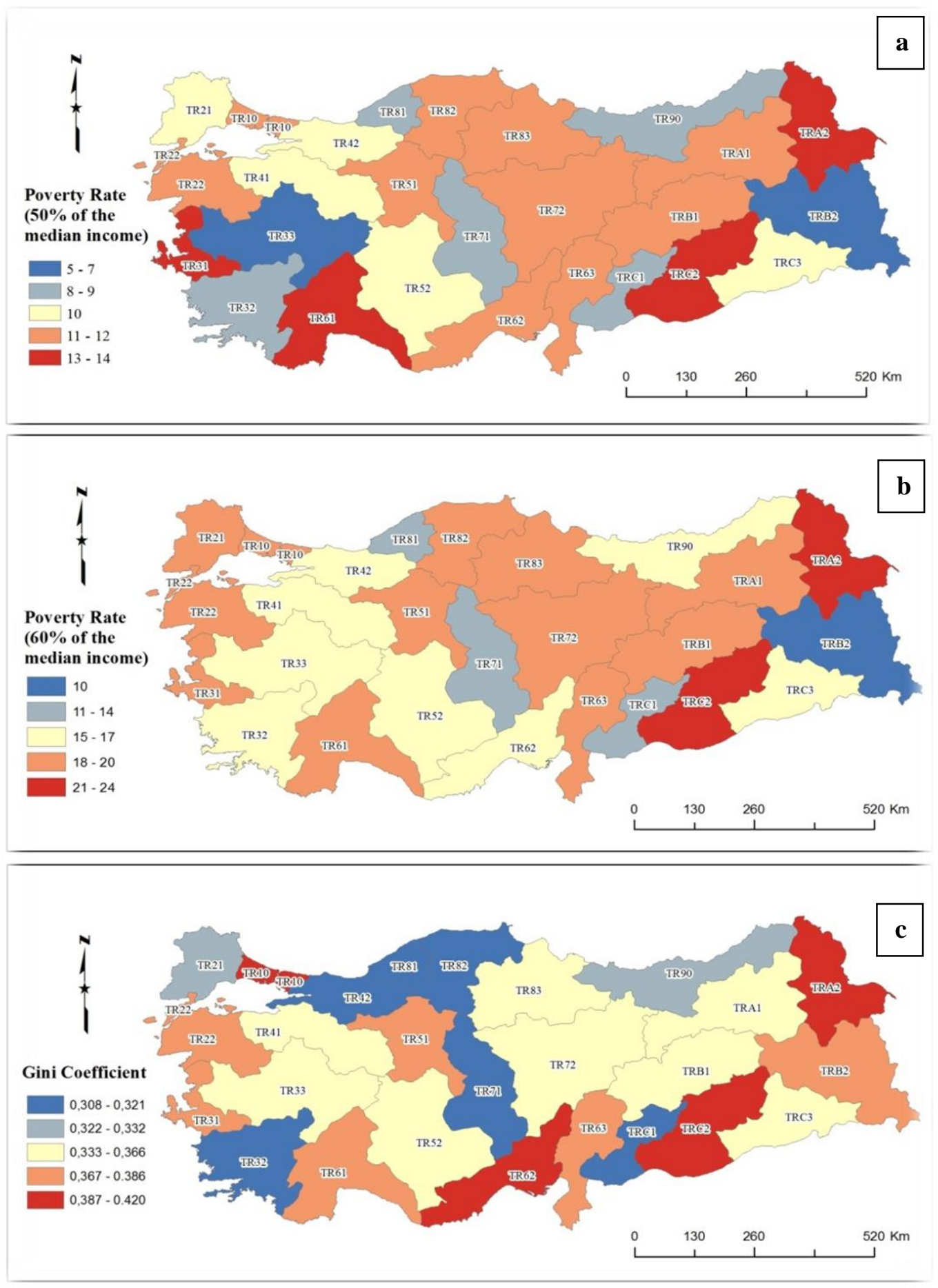

Figure 5. Spatial Distribution of a) population living under poverty rate, b) population with poverty risk, c) Gini coefficient according to NUTS2

The area with the lowest rate of poverty is seen as TRB2. However this data may not reflect reality. When the data of few years ago is examined, it is seen that the area is the most disadvantaged area in poverty researches based on both gender and social indicators. The region has been the most disadvantaged area of the country for many years escepially due to terrorist incidents. Event for this reason, it is hosting the Southeastern Anatolia Development Project which is one of the biggest regional development projects of 
Republic of Turkey. The project is a gigantic investment totaling \$ 32 billion. Main objectives of the project are creation of new farming areas, the development of hydropower energy that allows industrial activities to expand east and southeast, and the development of the region in terms of transportation [5]. With this project, the region has progressed considerably in terms of agricultural production and energy production.

This region is where the terrorist operations concentrated in the last few years. The conflicts in the region has already caused massive displacement and the population living in the area has decreased significantly. The rapid increase of security forces and public personnel in the region in a short time may have caused the poverty rate to seem low.

Another area with the lowest poverty rates following this area is the TR33 region. The provinces in the region are mainly specialized in textile and mining, especially in stonebased industries. The region is also close to important market areas, primarily Ankara and Izmir. However, this is the region where the rates of inequality are high. For this reason, the inequality is high even in the areas where poverty is the lowest in Turkey, indicating that the poverty problem is still an unsolved socio-economic problem.

\section{DISCUSSION}

When the theories on the causes of poverty are examined, structural economic changes, especially neo-liberal policies, human and physical capital, culture, social exclusion and public policies are the most striking determinants. Apart from these indicators, one of the decisive and influential factors in poverty is the migration. Because nowadays the phenomenon of migration is an integral part of the global economy. Both internal and external migration can be a significant development and poverty inducement for individuals and households living at the source and destination points in a regional sense as well as for the national economy at large.

This study examines the spatial distribution and regional characteristics of poverty in Turkey. According to this, when the causes of the distribution of poverty in the country are examined, it is possible to say that most of the reasons mentioned above are effective ones. When the situation of poverty in Turkey is examined, it is seen that the high inequality rates, physical capital, terrorism and migration are the most important factors affecting the distribution of poverty. As a result, the reason of poverty can be differentiated in different regions even in a single country, as initially stated, and Turkey is the best model of this statement.

Although the poverty rates tend to decrease in Turkey in recent years, it is not possible to mention a total improvement in the distribution of poverty. Both the ratio of the population with the risk of poverty and income inequality are high. Tekeli [11] states that the current dynamics of development of the country consistently produce this unequal table. For this reason, it is possible to say that one of the most important problems that Turkey will face in combating poverty in the near future is spatial inequality in poverty and inequality rates. 


\section{REFERENCES}

[1] AFAD, https://www.afad.gov.tr/tr/3619/AFAD-Baskani-ABDdeki-SuriyeliMulteciler-Konferansinda-Konustu (Access: 07.02.2017).

[2] Akgiş, Ö. Spatial Distribution of Happiness as a Well-Being Indicator in Turkey, Türk Coğrafya Dergisi, Turkey, vol. 65, pp. 69-76, 2015

[3] Akgiş, Ö. \& Karakaş, E. İç Göçün Bölgesel Yoksulluk Oranları Üzerindeki Etkisinin Belirlenmesi: TR6 Akdeniz Bölgesi Örneği, International Geography Symposium, Turkey, 2016.

[4] Baker, J. L. \& Grosh, M. E. Poverty Reduction Through Geographic Targetting: How Well Does It Work?, World Development, vol. 22, pp. 983-995, 1995.

[5] Bazin. M. \& De Tapia, S. Türkiye Coğrafyası, İletişim Yayınları, İstanbul, 2015.

[6] Bigman, D. \& Fofack, H. Geographical Targeting for Poverty Alleviation: Methodolgy and Applications, The World Bank, USA, 2000

[7] Coşkun, M. N., 2012, Türkiye'de Yoksulluk: Bölgesel Farklılıklar ve Yoksulluğun Profili. Bölgesel Gelişme Stratejileri ve Akdeniz Ekonomisi (Ed. Haluk Erlat).

[8] Henninger, N. Mapping and Geographic Analysis of Human Welfare and Poverty: Review and Assessment, World Resources Institute, USA, 1998.

[9] Ravallion, M. \& Wodon, Q. Poor Areas or Only Poor People?, World Bank Policy Research Working Paper 1798, 1997

[10] Ravallion, M. \& Huppi, M. Measuring Changes in Poverty: A Methodological Case Study of Indonesia During an Adjustment Period, The World Bank Economic Review, USA, vol. 5, pp. 57-82, 1991

[11] Tekeli, İ. Türkiye'de Bölgesel Eşitsizlik ve Bölge Planlama Yazıları, Tarih Vakfı Yurt Yayınları, İstanbul, 2011 